\title{
Influence of Demographic Variables on Consumer Ethnocentrism: Case of Rajasthan, India
}

\author{
Khushbu Agarwal \\ Wisdom, Banasthali Vidhyapith, Newai - 304022, Rajasthan (India)
}

\begin{abstract}
This research will attempt to explore and analyse the belongings of several demographic variables i.e. gender, age, education level, income level, and nature of dwelling on the consumer ethnocentric tendencies among consumers of Rajasthan. Five independent variables gender, age, education level, income level, and nature of dwelling are taken to check the ethnocentric behaviour of respondents towards buying Fast Moving Consumer Goods. Respondents were approached from Jaipur, Rajasthan and 5-point Likert was used to measure the variables. SPSS version 21 was used for data analyses to instigate with the demographic profile of the respondents. The investigation of the differences between subgroups in the demographic variables was tested using independent sample T-test and one-way ANOVA. From results it was concluded that Indians above 31 years were more ethnocentric then younger generation and no significant relation was found between other demographic variables and ethnocentric tendencies of the consumer of Rajasthan.

Keywords: Consumer Ethnocentrism, Demographic characteristics - age, gender, income level, education level, Nature of dwelling

DOI: $10.7176 / \mathrm{JMCR} / 55-01$

Publication date: April $30^{\text {th }} 2019$

\section{INTRODUCTION}

Year 1991, witnessed a major change in Indian Economic scenario, wherein liberal trade policy, opened Indian economic borders for foreign investments. This helped the MNCs from all over the world to foray into Indian markets. The corporate's approach has been to capture international markets and this liberal trade policy benefitted significantly. Developed countries and their respective brands have an economic, technological and political edge over brands from developing countries. This has led to cut throat competition for the marketers. However, as the things stabilize depending upon the preferences of the society and government, scenario changes rapidly propelled by consumer behaviour. While entering and existing in foreign market, marketers are required to thoroughly understand the changing behaviour of globalised corporate environment. In the globalised business environment, several variables play an important role in shaping consumer behaviour, and Consumer Ethnocentrism is one of them. This research paper investigates the consumer ethnocentric tendencies of the Consumers of a developing country, precisely Rajasthan, India in this context and focuses the analysis on ethnocentric tendencies of the consumer of Rajasthan in context of demographic variables. There is abundance of foreign owned fast moving consumer goods MNC's in India, at competitive pricing, which are available with a wider advertisement appeal. There marketers have to consider the impact of ethnocentrism in society in which they are applying their market strategy to capture a sizable market share as each country has its own people, culture, purchasing decision making behaviour in selecting products amongst various foreign and domestic brands available.
\end{abstract}

\section{LITERATURE REVIEW}

\subsection{Consumer Ethnocentrism}

The term "Ethnocentrism" was first coined by Sumner in 1906. It was restricted to distinguish between in-group and out-groups humans, where the values of own group (in-group) are the antecedents of pride and attachment whereas animosity for the symbols of other group (Out-groups) (Levine \& Campbell, 1972)

"Consumer Ethnocentrism" (CET) was first coined by Prof. Terence A. Shimp and Subhash Sharma, for describing the moral belief held by Americans for purchasing foreign made products. A measure named CETSCALE was developed to moderately predict the level of Consumer Ethnocentrism (Shimp \& Sharma, 1987).

According to Schiffman \& Kanuk (2007) ethnocentrism reveals superiority of home grown products from others due to negative economic impact on domestic country.

Sharma, Shimp, \& Shin (1995) identified theoretical antecedents of CET. Good \& Huddleston (1995) investigated Ethnocentric tendencies of Polish and Russian Consumers to examine impact of CET on product selection decisions. Baumgartner \& Steenkamp (1998) measured CET in Belgium, Great Britain and Greece. Kucukemiroglu (1999) identified consumer market segments existing among Turkish consumers by using lifestyle patterns and ethnocentrism by interviewing respondents of Istanbul.

Kaynak \& Kara (2002) investigated ethnocentric behaviour of the Turkish Consumer. Balabanis \& 
Diamantopoulos (2004) examined the preference patterns of the $U K$ consumers for domestic products across eight product categories. Javalgi, Khare, C., \& Scherer (2005) investigated what directs consumer ethnocentric tendencies of French consumers, their perception towards imports and which subsequently reflects on their purchase intentions.

Bamfo (2012) examined the attitude of Ghanaian consumers towards indigenous goods of Ghana and concluded it below par to help boost local production. The article by CAZACU (2016) expalined moderately ethnocentric tendencies of Maldovan consumers by studying 113 respondents.

Zhang, Liu, \& Lan (2014) studied psychology of Chinese consumers and concluded that Developing country consumer are effected by negative stereotype and consider local brand to be worse in quality, technology and symbolic, while vice versa for foreign brand (positive stereotype).

Panda \& Misra studied COO image for the formation of Brand Equity with relation to three variables namely brand awareness, brand loyalty and brand distinctiveness.

Parts \& Vida (2013) investigated domestic vs. foreign product purchase behaviour of the consumers of alcohol products, clothes, and furniture of the consumers of Estonia and Slovenia on constructs of consumer cosmopolitanism, ethnocentrism, product quality and purchase intentions.

Sing \& Kewlani (2013) addressed the issue of validating CETSCALE in India by collecting data from management graduates and the findings of the research revealed that ethnocentrism of Indian consumers is multidimensional and is in a stage of transition. The results are consistent with earlier research and contrary to commonly held belief for Indian youth; ethnocentrism and favourable belief about foreign product go hand in hand.

A study by Bandyopadhyay (2014) reveals that ethnocentric Indian Consumers have positive perceptions of their own country and domestically-made products. However it does not interprets into any negative perception of US, Japan, South Korea or products originating from these countries.

The research of D Pentz, Terblanche, \& Boshoff (2014) investigated the possible relationship through online survey between consumer ethnocentrism and age, income and gender in South Africa. They studied samples on the basis of ethnic diversity. The outcomes of the study exposed an affirmative association between age and consumer ethnocentrism and negative association between consumer ethnocentrism and income. The connection between consumer ethnocentrism and gender differ between the two groups of respondents.

Ramsaran (2015) studied COO effect on Mauritian population. And concluded that $(27 \%+32 \%)$ of total respondents consulted product labelling in order to identify the Country of Origin of the respective products and COO was considered as an important factor in consumer decision making, but $91 \%$ claimed not to attach any special preference to Made-in-Mauritius label.

Mirzaeifar (2015) identified very impact of home entertainment appliances of Tehran City consumer's ethnocentrism and product knowledge on product's country of origin and purchase intention by measuring imported product purchase intention (PI), ethnocentrism (E), imported product knowledge (FPK), and country of origin (COO)

Since its introduction the term "Consumer Ethnocentrism" has been a reason of furore. Several researches have been done, which have further validated the importance of CETSCALE. Starting with America, this instrument has measured the purchase behaviour of the consumer world over, studying the different product lines like mobile phones, home entertainment appliances, alcohol products, clothes and furniture etc.

While all these studies focused on "Made-in" dimensions, this research paper had focused on "ownership" of the product. Therefore, all the questions were modified suiting to the "Ownership" dimension rather than the "Made-in-country" dimension.

For example: The FMCG products, Kissan Ketchup, Knorr Soups, Kwality walls icecream, Surf excel, Wheel and Rin detergent, domex bathroom cleaner, Axe, Closeup, clinic plus, dove, fair n lovely, Hamam, indulekha and Vaseline, present in Indian Market are almost Made in India, but their ownership rests with Hindustan Unilever Ltd. whose Holding Company is Anglo-Dutch Company Unilever holding a stake of 67.21\% in HUL (as on Mar, 16). Consequently, though these basic FMCG are made in India, but their ownership is foreign.

Therefore, this consumer ethnocentrism research, deals with the ownership angle irrespective of Made in location image.

\subsection{Demographic Antecedents}

Numerous researches explored the association between consumer ethnocentrism and demographic variables (D Pentz, Terblanche, \& Boshoff, 2014), (Petrovicova \& Gibalova, 2014), (Balabanis \& Diamantopoulos, 2004) and have confirmed that the degree of consumer ethnocentrism is a function of demographic characteristics, socio-economic factor and regional economic factor (Kumar et. al 2011, Renko et. al, 2012, Aziz et. al 2014, Alpaslan, 2014, Lopez et. al 2016)

Javalgi, Khare, Gross, \& Scherer (2005) explored ethnocentrism studies and identified frequently used 
demographic variables as age, gender, education and income. Based on the analysis of Javalgi et. al. (2005) and Rajasthan being a developing state, a demographic concern and market division here is Urban and rural, therefore apart from the four demographic variables, nature of dwelling is also included in this study.

Although there were, few studies, as well which for instance investigated no relationship between the demographic variables and ethnocentrism, For example: Sharma, et. al (1995) and Festervand, (1985) concluded no substantial association between age and consumer ethnocentrism. Likewise, Han (1990), De Ruyter, Van Bigelen, \& Wetzels (1998) and Keillor, D'Amico, \& Horton (2001) identified that income is not significant in measuring consumer ethnocentrism. Brodowsky et. al. (2004) investigated no substantial association between education level and consumer ethnocentrism. De Ruyter et. al (1998), Keillor et. al (2001), Brodowsky et. al (2004) and Matić (2013) identified no significant gender differance on consumer ethnocentrism.

Wheras some studies reported existence of the relationship betweeen demographic variables and consumer ethnocentrism, like Tan \& farley (1987) stated significant positive relationship between income and consumer ethnocentrism, where as Matić (2013) identified negative relationship between income and consumer ethnocentrism. Significant gender differences on consumer ethnocecentrism were noticed by Balabanis \& Diamantopoulos (2004), Han (1990), Kaynak \& Kara (2002). However, Watson et. al (2000), Vida et. al (2001) Lee et. al (2003), Balabanis et. al (2004) and Matić (2013) identified older generation to be more ethnocentric. Whereas, Watson et. al (2000), Lee et. al (2003), Balabanis et. al (2004), Javalgi et. al (2005) and Matić (2013) accredited less educated people to be more ethnocentric. Keillor et. al (2001) and Lee et. al (2003) found lower income consumers to be more ethnocentric.

\subsection{Significance of study}

So far very few studies have been undertook on identifying effect of demographic antecedents on consumer ethnocentrism of Indian consumers and almost negligible on the Rajasthan State, therefore this study will examine the effect of demographic variables like age, gender, education, income and nature of dwelling on consumer ethnocentric tendencies among consumers of Rajasthan.

\section{RESEARCH MODEL}

As illustrated in previous researches, Consumer Ethnocentric tendencies are effects by the demographic antecedents. Thus this research model studies the impact of age, income, education, gender and nature of dwelling on consumer ethnocentric tendencies as shown in Figure 1.

\section{OBJECTIVE OF STUDY}

The objective of the research is to explore the effect of demographic variables on consumer ethnocentrism in the state of Rajasthan. This study discourses a gap in the field of consumer ethnocentrism in the state of Rajasthan by studying the ethnocentric tendencies and their relationship with the demographic variables and endeavours to augment to the existing and limited research on consumer ethnocentrism in developing countries. Therefore, the objectives of the study are:

- To study the impact of demographic variables (age, gender, education, income and nature of dwelling) over the Rajasthan consumer's ethnocentrism.

- To investigate which consumer groups of Rajasthan are more ethnocentric, in terms of age, gender, education, income and nature of dwelling?

\section{HYPOTHESIS}

$\mathrm{H}_{1}$ : There is no substantial association between gender and consumer ethnocentrism.

$\mathrm{H} 1_{1}$ : There is a substantial association between gender and consumer ethnocentrism.

$\mathrm{H} 22_{0}$ : There is no substantial association between age and consumer ethnocentrism.

$\mathrm{H} 2_{1}$ : There is a substantial association between age and consumer ethnocentrism.

$\mathrm{H} 3_{0}$ : There is no substantial association between level of education and consumer ethnocentrism.

$\mathrm{H} 3_{1}$ : There is a substantial association between level of education and consumer ethnocentrism.

$\mathrm{H}_{4}$ : There is no substantial association between level of income and consumer ethnocentrism.

$\mathrm{H}_{1}$ : There is a substantial association between level of income and consumer ethnocentrism.

$\mathrm{H} 5_{0}$ : There is no substantial association between nature of dwelling and consumer ethnocentrism.

$\mathrm{H} 5_{1}$ : There is a substantial association between nature of dwelling and consumer ethnocentrism. 


\section{RESEARCH METHODOLOGY AND INSTRUMENT}

The data for this research is gathered from an Omnibus survey conducted for the doctoral thesis. The population for this study is defined as residents of Rajasthan. The sample entailed individuals above 18 years old, who are consuming fast moving consumer goods. No minimum income level was set, because in India dependent family members are generally not even aware of the family income, but they individually do add to a considerable level of disposable income to buy both domestic and foreign-owned goods. Samples of both male and female population residing in Rajasthan were drawn, to fulfil the objective of the study. To collect vide number of responses across different demographics, the data was collected vide self-administered questionnaires to be filled electronically and physically too. The next step consists of ensuring a pilot study to evaluate the comprehending ability of the questionnaire. A sample of 20 individuals 10 male and 10 female was taken to undertake the pilot study and with minor changes the questionnaire was circulated among the participants. A sample of 1500 individuals (750 males and 750 females) was randomly selected and were send an invitation to complete the questionnaire via internet (social media like whatsapp, facebook, linkedin, email). A total of 183 responses were received via online medium with a response rate of $12.20 \%$. To delve deeper penetration of responses across the state of Rajasthan, participants were contacted at the railway station and the bus stand of Jaipur. Jaipur, being the capital of Rajasthan, served as a convenient place to locate the commuters travelling throughout Rajasthan. A total of 1500 individuals were contacted with a response rate of $9.20 \%$, and 138 responses were collected.

\section{MEASURING INSTRUMENT}

Primary data is collected via a modified structured questionnaire, developed after being adapted from Shimp \& Sharma (1987) along with demographic variables. The adptations were restricted to the change in name of the country as India from America. And change in "Made in" location to "Indian-owned". This questionnaire consisted of questions, on a five point Likert scale with options 1-5 where 1 represents "strongly disagree" to 5 representing "strongly agree". The demographic data of age, gender, level of education completed, income and nature of dwelling of respondents is collected on categorical and nominal scales. After completion of pilot study, minor modifications were made to incorporate the feedback of the respondents in the questionnaire.

The items used in the questionnaire are enumerated in Table 1 and Table 2.

Out of 3000 invitations only 321 responses were received. They were all substantially complete and were considered for the analysis. For analysis SPSS version 21 is used. Table 3 represents the demographic profile of the respondents.

\section{RESEARCH FINDINGS}

In the first phase of data analysis, the researcher identified descriptive statistics of the nine item ethnocentrism CETSCALE. The results are illustrated in Table 4: Descriptive Statistics.

The ethnocentric measure used consisted of an inventory of nine attitudinal statements with a five-pointlikert scale where'1' represented "strongly disagree" and ' 5 'represented "strongly agree" and ' 3 ' signifies "neutral". The average score of all these nine items for 298 respondents of Rajasthan is 3.24, which indicates that Indians are ethnocentric with regards to the purchase of "Indian-owned" FMCG products. The highest rating was for statement number 3, "Buy Indian-owned products, keep India earning", while the lowest (2.65) was on item no. 5, "purchasing foreign-owned products is un-indian". Both are in line with the results of previous research of Lopez \& Zunjur (2016), which studied consumer ethnocentrism of pimri-chinchwad, pune.

\subsection{The reliability of the CETSCALE}

To measure the reliability of CETSCALE, Cronbach's Alpha was used as listed in Table 5: Reliability Statistics Value of Cronback Alpha is 0.903 , which indicate high level of internal consistency for our nine items related to ethnocentric tendencies of Consumer of Rajasthan state.

While exploring the differences between demographic variables that were nominally scaled and ethnocentrism scores, independent-sample t-tests were conducted. For interval-scaled independent variables, one way ANOVA was used.

\subsection{EMPIRICAL RESULTS}

\subsubsection{Effect of Gender on consumer ethnocentrism tendencies of respondents of Rajasthan}

To evaluate the effect of nominally scaled demographic variable, Gender on consumer ethnocentrism, the researcher conducted a T-test, whose results are depicted in Table 6

Significance value (2-tailed) for t-test for Equality of Means is greater than 0.05. It indicates that there is no significant relation between Gender and Consumer Ethnocentrism. Hence we accept null hypothesis.

\subsubsection{One way ANOVA with age}

Table 7, illustrates the values of one way ANOVA with age. The significance value is less than $0.05(\mathrm{p}<0.05)$, thus it specifies that there is substantial association between age and consumer ethnocentrism. Hence we reject 
null and accept alternate hypothesis.

\subsubsection{One way ANOVA with education}

Table 8 elaborates the results of one way ANOVA with education. The significance Value is greater than 0.05 . Thus it indicates no substantial association between education level and Consumer Ethnocentrism. Hence we accept null H3. That means education level of consumer and consumer ethnocentrism tendency are not related to each other.

\subsubsection{One way ANOVA with income}

Table 9 illustrates results of one way ANOVA with income. The significance Value is greater than 0.05 . Thus it indicates no substantial connection between income level and Consumer Ethnocentrism. Hence we accept null H4. That means income level of consumer and consumer ethnocentrism tendency are not related to each other.

\subsubsection{T-test with nature of dwelling}

Table 10 elaborates on the results of T-test with nature of Dwelling. The significance Value is greater than 0.05 . Thus it indicates no substantial association between nature of dwelling and Consumer Ethnocentrism. Hence we reject $\mathrm{H} 5$ and accept null $\mathrm{H} 5$. That means nature of dwelling and consumer ethnocentrism tendency are not related to each other.

\section{FINDINGS}

The main concentration of this research is to scrutinize the presence of consumer ethnocentrism and the impact of demographic variables in a developing state of a developing country i.e. Rajasthan, India. In the current globalised competitive Indian market, marketers' knowledge of ethnocentric tendencies and their demographic antecedents will assist in devising effective integrative marketing communication strategies for both foreign and Indian retailers.

This study recognizes that there is no substantial connection between gender and consumer ethnocentrism. Although many past studies like Balabanis et. al (2004), Han (1990), Kaynak \& Kara (2002) identified substantial association between gender and ethnocentric tendencies. But in this study it was difficult to determine, if either of females or males are more ethnocentric. So the findings of this study didnot support the previous studies, one of the resons could be a dispropotionate sample, wherein female respondents are $36.9 \%$ only and male repondents are $63.09 \%$. Had it been a proportionate sample findings might have shown different relationships.

Age is significantly positively related with the ethnocentric tendencies. The consumers within 18 to 30 years are considered less ethnocentric with an average mean of 2.93 whereas the older generation 31 and above are more ethnocentric with an average mean of 3.37. Since age is positively related, Indian retailers could target the consumers above 30 years to buy, Indian goods, by touting products' Swadeshi appeal. And they could incorporate global approach for quality enrichment, branding, labelling, packaging and marketing strategies to target younger generation.

Education level and consumer ethnocentrism have no substantial connection. Previous studies like Watson et. al (2000), Lee et. al (2003), Balabanis et. al (2004), Javalgi et. al (2005) and Matić (2013) acknowledged less educated people to be more ethnocentric. But the respondents of Rajasthan as in this study showed no explicit relation between education and ethnocentric tendencies.

It was found that there is no substantial association between Income and consumer ethnocentrism. Findings of this research does not match with the past findings where Keillor et. al (2001) and Lee et. al (2003) found lower income group to be more ethnocentric.

Nature of dwelling and consumer ethnocentrism, also do not have any significant relation in this study. Very few of the previous studies have identified the relationship between nature of dwelling and consumer ethnocentrism. And the results of this study could also be skewed as the majority of respondents are from urban dwelling $(85.93 \%)$. Had the number of respondents were proportionate to each other, it could have indicated different results.

\section{RESEARCH IMPLICATIONS}

Findings of the research bring about significant strategy connotation for the business firms, especially the domestic ones. In the context of creating major niche markets for multinational firms operating in the domain of Indian Fast Moving consumer goods market, two major niche markets could be drawn to distinguish between ethnocentric and non-ethnocentric consumers. One group consist of younger generation of Rajasthan, who are less ethnocentric- in this case the consumers between 18 years to 30 years and other group are older generation from the age group of 31 years to 51 years and above, who are more ethnocentric. Therefore the manufacturers and marketers of indigenous products may find it useful to place product in the segment of people over 30 years of age. So they can focus more on this segment for positioning. On the other hand marketers of foreign brands should focus primarily on less ethnocentric (young people) segment for penetration in India. 


\section{LIMITATIONS OF THE STUDY}

Although the present research work contributes to the marketing literature, researcher wants to draw attention to certain limitation. Firstly, this study incorporates only few demographic variables as antecedents to ethnocentrism, whereas many other variables as Economic and political factors, materialism, value orientation, nationalism, consumer life styles orientation, universalism, dogmatism, benevolence, animosity and hostility as antecedents to ethnocentrism. Secondly, the study is conducted in Rajasthan state of India. It could have been conducted pan India, to understand consumer ethnocentrism and the impact of demographic antecedents. Thirdly, the present sample is more skewed towards urban dwellers and male respondents, a proportionate sample could have been better to improve generalisations of results. Finally, this research does not incorporate the xenophobic attitude of animosity towards the products of a particular country. Future researches in this context could study consumers' xenophobia attitude toward products from various countries.

\section{Reference}

Alpaslan, D. Y. (2014, March). The role of consumer hostility and consumer ethnocentrism on the intention of buying foreign goods: A case study on Iranian, Turkish and Azerbijani Consumers. European Journal of Business and Social Sciences, 2(12), 38-55.

Aziz, S., Bahadur, W., Sarwar, B., Farooq, R., \& Arshad, M. (2014, June). Investigating the Role of Demographic Characteristics on Consumer Ethnocentrism and Buying Behavior. International Review of Management and Business Research, 3(2), 885-893.

Balabanis, G., \& Diamantopoulos, A. (2004). Domestic country bias, country-of-origin effects, and consumer ethnocentrism: a multidimensional unfolding approach. Journal of the Academy of Marketing.

Brodowsky, G. H., Tang, J., \& Meilich, O. (2004). Managing country-of-origin choices: competitive advantages and opportunities. . International Business Review, 729-748.

D Pentz, C., Terblanche, N. S., \& Boshoff, C. (2014). Demographics and consumer ethnocentrism in a developing country context: a South African study. SAJEMS, 4, 412-426.

De Ruyter, K., Van Bigelen, M., \& Wetzels, M. (1998). Consumer ethnocentrism in international services marketing. International Business Review, 7, 185-202.

Festervand, T. L. (1985). Consumers' perceptions of imports: An update and extension. Akron Business and Economic review, 31-36.

Han, C. (1990). Testing the role of country image in consumer choice behaviour. European Journal of Marketing, 24(6), 24-39.

Javalgi, Khare, R., Gross, V., \& Scherer, A. (2005). An application of the consumer ethnocentrism model to French consumers. International Business Review, 14(3), 325-344.

Kaynak, E., \& Kara, A. (2002). Consumer perceptions of foreign products: an analysis of product-country images and ethnocentrism. . European Journal of Marketing, 928-949.

Keillor, B., D'Amico, M., \& Horton, V. (2001). Global consumer tendencies. Journal of Psychology \& Marketing , 1-19.

Kumar, A., Fairhurst, A., \& Kim, Y.-K. (2011, September). Ethnocentric tendencies of Indian consumers: impact on preference for domestic versus foreign products. The International Review of Retail, Distribution and Consumer Research, 21(4), 323-341.

Lee, W. N., Hong, J. Y., \& Lee, S. J. (2003). Communicating with American consumers in the post 9/11 climate: an empirical investigation of consumer ethnocentrism in the United States. International Journal of Advertising, 22(4), 487-510.

Levine, R., \& Campbell, D. T. (1972). Ethnocentrcm: Theories of Conflict, Ethnic Attitude and Group Behaviour. New York: John Wiley \& Sons, Inc.

Lopez, J., \& Zunjur, A. (2016). A Study of Consumer Ethnocentrism in thePimpri- Chinchwad Region, Pune. IOSR Journal of Business and Management, 18(2), 72-78.

Matić, M. (2013). The Impact of Demographic and Socio-Psychological Factors on Consumers Ethnocentric Tendencies in Croatia. Economic Research-Ekonomska, 1-14.

Petrovicova, J. T., \& Gibalova, M. (2014). Measurement of Consumer Ethnocentrism of Slovak Consumers. International Review of Management and Marketing, 247-258.

Renko, N., Karanović, B. C., \& Matić, M. (2012). Influence of Consumer Ethnocentrism on purchase intentions: case of Crotia. Ekon. Misao Praksa DBK. God XXL, 529-544.

Samiee, S., Shimp, T., \& Sharma, S. (2005). Brand origin recognition accuracy: its antecedents and consumers' cognitive limitations. Journal of International Business Studies(36), 379-397.

Sharma, S., Shimp, T. A., \& Shin, J. (1995, December). Consumer ethnocentrism: A test of antecedents and moderators. Journal of the Academy of Marketing Science, 23(1), 26-37.

Shimp, T. A., \& Sharma, S. (1987, August). Consumer Ethnocentrism: Construction and Validation of the CETSCALE. Journal of Marketing Research, 24(3), 280-289. 
Tan, C. T., \& farley, J. U. (1987). The impact of cultural patterns on cognition and intention in Singapore. . Journal of Consumer Research, 540-544.

Vida, I., \& Dmitrovic, T. (2001). An empirical analysis of consumer purchasing behavior in former Yugoslav markets. . Economic and Business Review, 191-207.

Watson, J. J., \& Wright, K. (2000). Consumer ethnocentrism and attitudes toward domestic and foreign products. European Journal of Marketing, 34, 1149-1166.

Author - Khushbu Agarwal is Doctoral Research scholar at Banasthali Vidhyapith, Newai, where she ardently researches and writes on Swadeshi FMCG. She graduated from University of Rajasthan, with bachelor's degree in business administration in 2007. After graduation, she pursued full time MBA from Institute of Management Technology, Ghaziabad (07-09). She is having a work experience of 2.5 years with IDBI Bank as Assistant manager and has served as customer service manager and team member, cheque management systems (CMS) and later during 4 years with Agarwal Iron Foundry, she worked as chief corresponding executive editor.

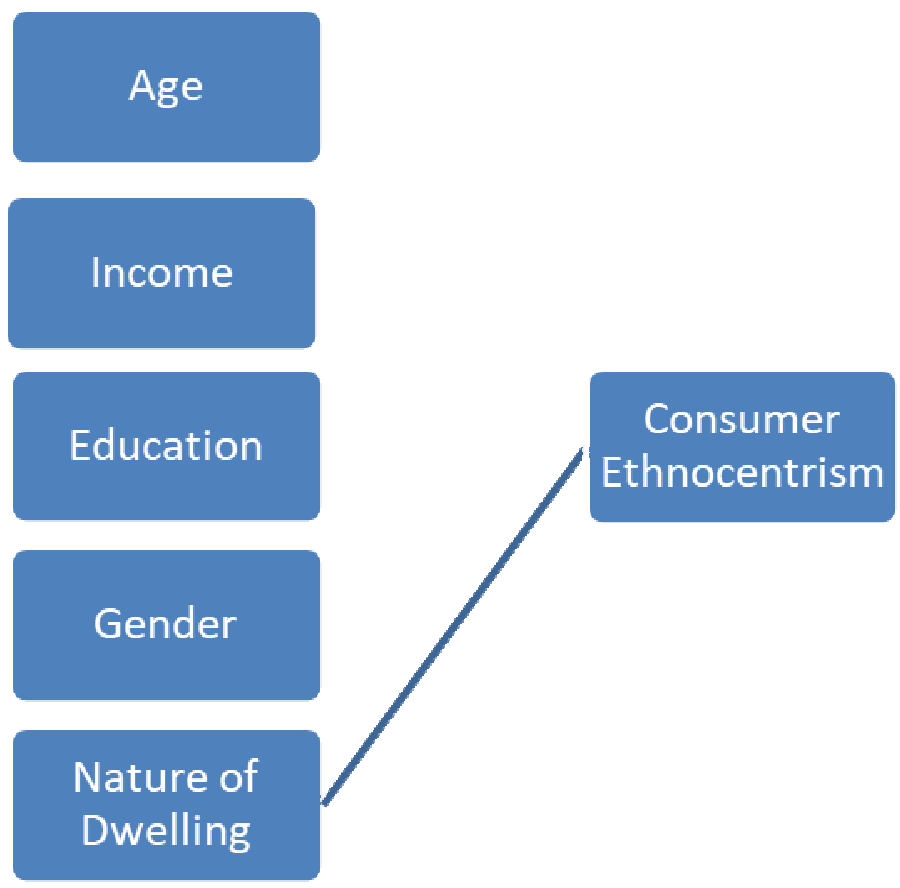

Figure 1 Research Model

Table 1: Items used in Questionnaire to measure consumer ethnocentrism

Items used

Indian Consumers should always buy Indian Owned products instead of foreign owned.

Only those products that are unavailable from Indian manufacturers should be bought from the foreign manufacturers.

Buy Indian Owned products. Keep India earning.

Indian Owned products first, last and foremost.

Purchasing foreign owned products is un-Indian.

It is not right to purchase foreign owned products.

A real Indian should always buy Indian-Owned products.

Indians should not buy foreign owned products because it causes imbalance in balance of payments (BOP) and has adverse impact on Indian Entrepreneurship.

It may cost you more in long run, but you prefer to support Indian owned Products. 
Table 2: Demographic Variables

Please enter the District/town/city you live in? (Home Town / Residing Place)

Please enter your Residing State. (Home State / Residing State) ---------------------------------

Please enter your nature of dwelling. / Place of living (Urban/Rural)

Please select your Gender? Male/Female

How old are you?

\begin{tabular}{|l|l|l|l|l|l|l|}
\hline Below 20 & $20-25$ Years & $26-30$ years & $31-35$ years & $36-40$ years & $41-50$ years & 51 and above \\
\hline
\end{tabular}

Please enter your Level of Education

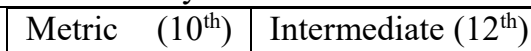

and Below

Please enter your average annual income

\begin{tabular}{|ll|l|l|l|l|l|l|}
\hline Below & Rs & Rs 50000- & Rs 450001- & Rs 600001- & Rs 12,00,001 - & Rs 24,00,001 \\
50000 & & 450000 & $6,00,000$ & 1200000 & $24,00,000$ & lakh and above \\
\hline
\end{tabular}

Table 3: Descriptive Statistics

\begin{tabular}{|l|l|l|l|l|}
\hline $\begin{array}{l}\text { Item } \\
\text { Code }\end{array}$ & Items & $\mathrm{N}$ & Mean & $\begin{array}{l}\text { Std. } \\
\text { Deviation }\end{array}$ \\
\hline E3 & Buy Indian Owned products. Keep India earning. & 312 & 3.83 & 1.235 \\
\hline E9 & $\begin{array}{l}\text { It may cost you more in long run, but you prefer to support Indian } \\
\text { owned Products. }\end{array}$ & 312 & 3.57 & 1.201 \\
\hline E4 & Indian Owned products first, last and foremost. & 309 & 3.46 & 1.239 \\
\hline E1 & $\begin{array}{l}\text { Indian Consumers should always buy Indian Owned products } \\
\text { instead of foreign owned. }\end{array}$ & 316 & 3.45 & 1.3 \\
\hline E2 & $\begin{array}{l}\text { Only those products that are unavailable from Indian manufacturers } \\
\text { should be bought from the foreign manufacturers. }\end{array}$ & 314 & 3.27 & 1.235 \\
\hline & $\begin{array}{l}\text { Indians should not buy foreign owned products because it causes } \\
\text { imbalance in balance of payments (BOP) and has adverse impact } \\
\text { E8 Indian Entrepreneurship. }\end{array}$ & 312 & 3.23 & 1.285 \\
\hline E7 & A real Indian should always buy Indian-Owned products. & 312 & 3.06 & 1.365 \\
\hline E6 & It is not right to purchase foreign owned products. & 310 & 2.66 & 1.341 \\
\hline E5 & Purchasing foreign owned products is un-Indian. & 313 & 2.65 & 1.31 \\
\hline $\begin{array}{l}\text { Valid N } \\
\text { (listwise) }\end{array}$ & & 298 & & \\
\hline & Average Mean Score & 3.242222 & \\
\hline
\end{tabular}

Table 4: Reliability Statistics

\begin{tabular}{|c|c|c|}
\hline Cronbach's Alpha & Cronbach's Alpha Based on Standardized Items & $\mathrm{N}$ of Items \\
\hline .903 & .902 & 9 \\
\hline
\end{tabular}

Table 5: Independent Samples Test

\begin{tabular}{|c|c|c|c|c|c|c|c|c|c|c|}
\hline & \multicolumn{2}{|c|}{$\begin{array}{c}\text { Levene's } \\
\text { Test for } \\
\text { Equality of } \\
\text { Variances }\end{array}$} & \multicolumn{7}{|c|}{ t-test for Equality of Means } \\
\hline & & \multirow[t]{2}{*}{$\mathrm{F}$} & \multirow[t]{2}{*}{ Sig. } & \multirow[t]{2}{*}{$\mathrm{t}$} & \multirow[t]{2}{*}{$\overline{\mathrm{Df}}$} & \multirow[t]{2}{*}{$\begin{array}{l}\text { Sig. } \\
(2- \\
\text { tailed })\end{array}$} & \multirow[t]{2}{*}{$\begin{array}{c}\text { Mean } \\
\text { Difference }\end{array}$} & \multirow[t]{2}{*}{$\begin{array}{l}\text { Std. Error } \\
\text { Difference }\end{array}$} & \multicolumn{2}{|c|}{$\begin{array}{l}95 \% \text { Confidence } \\
\text { Interval of the } \\
\text { Difference }\end{array}$} \\
\hline & & & & & & & & & Lower & Upper \\
\hline \multirow[b]{2}{*}{ CETvalue } & $\begin{array}{l}\text { Equal } \\
\text { variances } \\
\text { assumed } \\
\end{array}$ & 1.4 & 0.24 & 1.21 & 317 & 0.228 & 0.14398 & 0.11922 & -0.0906 & 0.3785 \\
\hline & $\begin{array}{l}\text { Equal } \\
\text { variances } \\
\text { not } \\
\text { assumed }\end{array}$ & & & 1.24 & 264.29 & 0.217 & 0.14398 & 0.11629 & -0.085 & 0.373 \\
\hline
\end{tabular}


Table 6: Anova with Age

ANOVA

CETvalue

\begin{tabular}{|l|r|r|r|r|r|}
\hline & Sum of Squares & df & Mean Square & F & Sig. \\
\hline Between Groups & 26.091 & 6 & 4.349 & 4.376 & .000 \\
Within Groups & 312.031 & 314 & .994 & & \\
Total & 338.122 & 320 & & & \\
\hline
\end{tabular}

Table 7: Anova with education

CETvalue

ANOVA

\begin{tabular}{|l|r|r|r|r|r|}
\hline & Sum of Squares & df & Mean Square & F & Sig. \\
\hline Between Groups & .939 & 4 & .235 & .220 & .927 \\
Within Groups & 335.688 & 314 & 1.069 & & \\
Total & 336.628 & 318 & & & \\
\hline
\end{tabular}

Table 8: Anova with income

CETvalue

ANOVA

\begin{tabular}{|l|r|r|r|r|r|}
\hline & Sum of Squares & df & Mean Square & \multicolumn{1}{|c|}{ F } & Sig. \\
\hline Between Groups & 7.370 & 5 & 1.474 & 1.564 & .170 \\
Within Groups & 276.072 & 293 & .942 & & \\
Total & 283.442 & 298 & & & \\
\hline
\end{tabular}

Table 9: $T$ test with nature of dweling

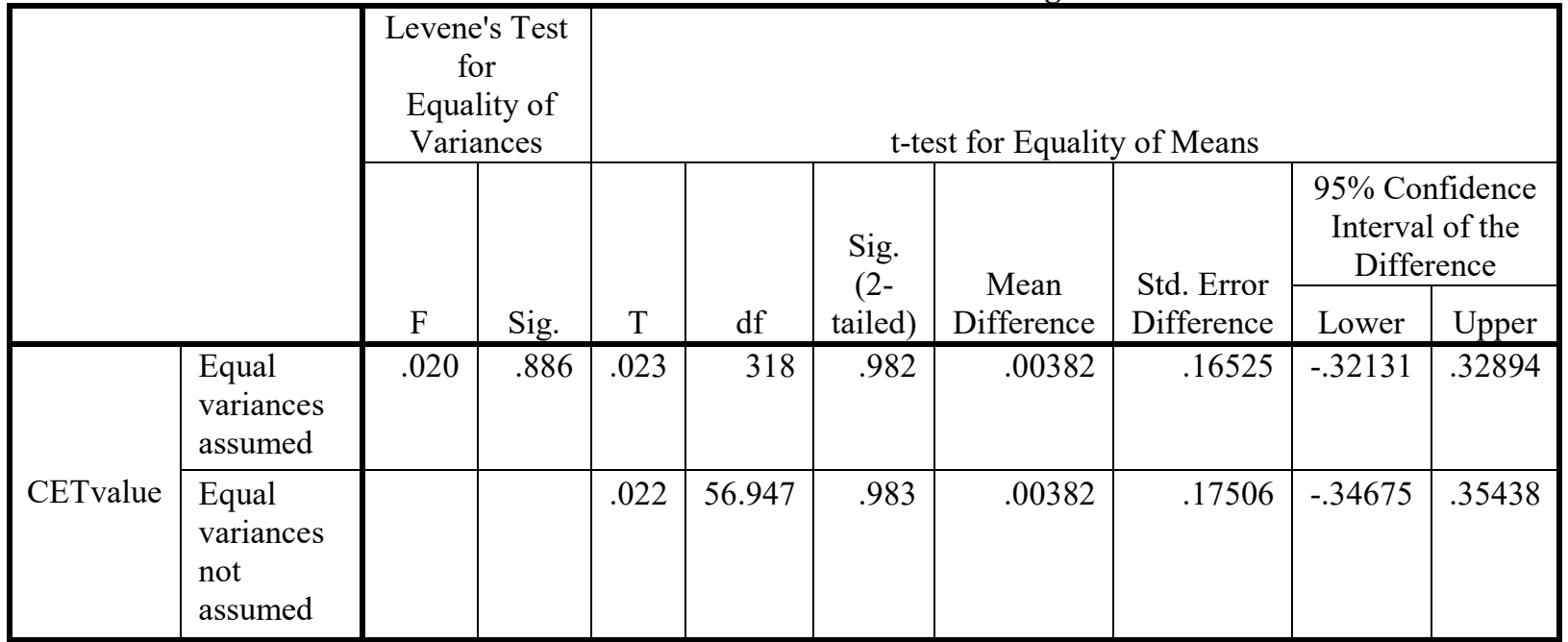

